\title{
Collaborative Work in Mathematics Teacher Education
}

\section{Trabalho Colaborativo na Formação de Professores de Matemática}

\author{
Bárbara Silva Gumiero*a; Vinícius Pazuch ${ }^{\mathrm{a}}$
}

${ }^{a}$ Federal University of ABC. SP, Brazil.

*E-mail. barbaragumiero@gmail.com

\begin{abstract}
Collaborative work improves teacher education through the interaction between people, narrowing the distance between university and schools and between researchers and preservice or in-service teachers. This systematic literature review included works published in databases like Scielo, ERIC, PsycINFO, Web of Science, and MathEduc. In total, 12 papers were reviewed to identify which factors present in collaborative environments favor the formation of teaching processes in Mathematics Education. The results show that class planning, teaching practices, and knowledge production provide a contribution to mathematics teacher education.
\end{abstract}

Keywords: Teacher Collaboration. Teacher Education. Mathematics Education. Systematic Review.

\section{Resumo}

O trabalho colaborativo potencializa a formação de professores por meio da interação entre pessoas, aproximando a universidade da escola e os pesquisadores dos professores em formação ou já atuantes. Esta revisão sistemática da literatura incluiu trabalhos publicados em bases de dados como Scielo, ERIC, PsycINFO, Web of Science e MathEduc. No total, 12 artigos foram revisados para identificar quais fatores presentes em ambientes colaborativos favorecem a constituição de processos formativos em Educação Matemática. Os resultados mostram que o planejamento de aulas, a prática docente e a produção de conhecimentos contribuem para a formação de professores de matemática.

Palavras-chave: Colaboração entre Professores. Formação de Professores. Educação Matemática. Revisão Sistemática.

\section{Introduction}

Collaborative work is widely discussed in mathematics teacher education. According to the Oxford Advanced Learner's Dictionary, the adjective collaborative means "involving, or done by, several people or groups of people working together". However, in some contexts it may be considered a synonym of cooperative. In the context of the present study the two terms have to be distinguished. For Robutti et al. (2016), cooperation includes people offering contribution to several steps of a task, while collaboration alludes to a relational system between individuals or a process characterized by unforeseen events, highlighting the need for negotiation and decision-making. Bednarz, Fiorentini, \& Huang (2011) present a similar notion. For the authors, cooperation means sharing tasks in a project, while collaboration is based on a relationship in which participants listen to one another, engaging in suggestions, sharing experiences, and interacting constantly, therefore paving the way to new possibilities.

The mindset in school environments may be strongly characterized by individualism and isolation, which makes team work more difficult. This poses a challenge to teachers to collectively reflect on what they do, how they do it and why (Hadar \& Brody, 2010). On the other hand, research shows that small groups of teachers may improve teaching based on collaborative work (Cozza, 2010; Healy \& Santos, 2014; Solano, Rico \& Leal, 2017; Souza \& Oliveira, 2013; Strutchens \& Martin, 2013).

Whether such groups are collaborative efforts, communities of practice, or simply groups dedicated to collaborative projects, they share a few interesting characteristics, like shared leadership and responsibility; mutual support and respect; voluntariety, identity, and spontaneity; and the disposition to share knowledge and experiences as well as discuss aims and objectives (Bednarz, Fiorentini \& Huang, 2011; Crecci \& Fiorentini, 2011). In addition, these groups are not subjected to single truths, since all participants express what they think and feel, being ready to face disapproval and, therefore, feeling more inclined to change. In this context, all members work together and learn collaboratively, dialoguing, questioning, and reflecting on their roles in schools and society (Bednarz, Fiorentini \& Huang, 2011; Robutti et al., 2016).

Collaborative work may take place between teachers, between a teacher and a researcher as well as between students, teachers, and researchers. This increases the number of experiences that eventually promote the construction of new knowledge. Collaborative work also happens between students in the classroom or even between other agents in schools, like directors, supervisors, and parents of students. 
However, in this literature review we discuss studies with teachers, researchers, and/or preservice teachers, since our main topic is teacher education, whether preservice or inservice. In this sense, we address collaborative work in teacher education settings.

We understand that teacher education is the ground for discussion, planning, and reflection on classroom practices (Nacarato \& Grando, 2008). It is in these education scenarios that elementary, middle, and school teachers, university undergraduates and post-graduation students as well as professors consider pedagogical, didactic, and specific questions about mathematical concepts. We discuss the conjoint efforts in teacher education processes, when everyone enlarges knowledge and learns collectively. More specifically, elementary, middle, and high school teachers share experiences gathered in the classroom. On the other hand, university professors and students contribute knowledge in research.

In this context, our aim in the present study was to answer the following research question, How may collaborative work promote the development of teacher education processes for mathematics?

\section{Methodology}

The studies reviewed were retrieved form five databases, namely Scielo, ERIC, PsycINFO, Web of Science, and MathEduc. These databases include an expressive number of research on education in Brazil and elsewhere. In the article selection process we evaluated papers published in Portuguese, English, and Spanish. The studies published by Depaepe, Verschaffel \& Kelchtermans (2013) and Stahnke, Schueler \& Roesken-Winter (2016) were used as starting points to select papers. Nevertheless, these studies posed limitations concerning the language they were published in, since the references they cited were all in English. In the effort to enlarge the research scope and obtain more representative results, we included publications in other languages in the search.

The search terms were "teacher education", mathematics, and collaborative and were established based on the condition that they were present in abstracts, titles, and keywords. Quotation marks were used when necessary to ensure the search for one phrase. Search terms in English were used even in the queries in the Scielo database, which is published in Brazil, since the portal requires authors to provide titles, abstracts, and keywords in that language.

In total, 175 studies were initially retrieved (139 from ERIC, 26 from Web of Science, 25 from PsycINFO, 24 form MathEduc, and 5 from Scielo). Thirty-three papers had been published in more than one database. The studies were analyzed to confirm the presence of the query words in the fields selected. We observed that 109 studies did not include the query words used, but these papers were listed due to a query word classification embedded in the database, as in
ERIC. Two editorials were removed, and, by restricting works published between 2008 and 2017, 61 studies were reviewed.

At the end of this process, two exclusion criteria were adopted as a means to choose studies addressing the research question. The two exclusion criteria were (1) focus on mathematics education, which excluded papers about other themes such as pure mathematics, applied mathematics, and mathematics for engineering, and (2) characteristics of collaborative work, according to what is presented in the Introduction section of the present study. The use of these criteria left 12 articles to review. These studies are marked with an asterisk (*) in the References list.

This review was divided in two steps, namely a vertical analysis and a horizontal analysis (Depaepe, Verschaffel \& Kelchtermans, 2013). In the vertical analysis, each study represented an analytical unit. With that in mind, we wrote a summary based on the interpretation of each paper. This summary included topics that were addressed in the analysis. Nine aspects were considered: (1) objective of the study and/or research question - the focus of investigation; (2) methodology used; (3) the nature of the research; (4) the mathematical domain investigated; (5) the country the study was conducted; (6) education (preservice or in-service) of participant teachers; (7) the grades of students (for empirical studies carried out in the classroom), (8) the main results, and (9) conclusions.

Based on the results of the vertical analysis we carried out a horizontal analysis to compare studies based on the nine aspects described that were used as units of analysis. Similarities and differences were assessed to identify the main aspects addressed in the studies and the factors that promote mathematics teacher education processes.

\section{Results}

First we present the results of the vertical analysis, which summarize the contents of the studies included in this review.

\subsection{Vertical Analysis}

As a means to support the development of mathematical knowledge of teachers based on asynchronous online collaborative environment, Silverman \& Clay (2009) invited post-graduate students and teachers working in elementary, middle, and high schools to take part in a project involving the development of individual solutions to certain problems. Next, these solutions were discussed and published in a blog. The individual contribution of each participant became a permanent record of their early ideas, representing an accurate image of their constructions. The project was carried out in 2007 and 2008 in four courses, but only one was included in the study, which addressed the topic Number and Quantity. The authors observed that any comment in a public post affected the following posts and, therefore, the participants had the opportunity to learn with one another in these discussions. This confirmed that learning 
took place and proved the collaborative development of subjects in an online environment without the need for the concomitant presence of all participants. The article underscored two positive aspects of the collaborative online approach, namely the public and permanent nature of interactions and the stimulating potential of interactions to participants who were not directly engaged in the discussion. However, the authors acknowledged the difficulties that prevented online discussions, such as the hesitation to participate, lack of motivation, or the fact that participants who do not know what questions could be discussed. With that in mind, a few changes were adopted during the project and, therefore, a minimum number of posts and replies was defined and moderation efforts were made. Also, participants reviewed the solutions they had proposed and evaluated improvements in their publications, identifying the development of the teacher.

Table 1 lists the articles included in this systematic literature review.

Table 1 - Selected articles

\begin{tabular}{|c|c|c|}
\hline $\begin{array}{c}\text { Title } \\
\end{array}$ & Author & Country \\
\hline $\begin{array}{l}\text { Online Asynchronous Collaboration } \\
\text { in Mathematics Teacher Education } \\
\text { and the Development of Mathematical } \\
\text { Knowledge for Teaching }\end{array}$ & $\begin{array}{l}\text { Silverman } \\
\text { \& Clay } \\
(2009)\end{array}$ & USA \\
\hline $\begin{array}{l}\text { 'It's getting me thinking and I'm an } \\
\text { old cynic': exploring the relational } \\
\text { dynamics of mathematics teacher } \\
\text { change }\end{array}$ & $\begin{array}{l}\text { Boylan } \\
(2010)\end{array}$ & $\begin{array}{l}\text { United } \\
\text { Kingdom }\end{array}$ \\
\hline $\begin{array}{l}\text { Collaborative work and the use of } \\
\text { information and communication } \\
\text { technologies in Mathematics teacher } \\
\text { education }\end{array}$ & $\begin{array}{c}\text { Costa \& } \\
\text { Lins }(2010)\end{array}$ & Brazil \\
\hline $\begin{array}{l}\text { Transforming Teaching Into a } \\
\text { Collaborative Culture: An Attempt to } \\
\text { Create a Professional Development } \\
\text { School-University Partnership }\end{array}$ & $\begin{array}{l}\text { Cozza } \\
(2010)\end{array}$ & USA \\
\hline $\begin{array}{l}\text { Collaborative teacher inquiry as a tool } \\
\text { for building theory on the development } \\
\text { and use of rich mathematical tasks }\end{array}$ & $\begin{array}{c}\text { Slavit \& } \\
\text { Nelson } \\
(2010) \\
\end{array}$ & USA \\
\hline $\begin{array}{l}\text { Examining Beliefs and Practices of Self } \\
\text { and Others: Pivotal points for change } \\
\text { and growth for mathematics teacher } \\
\text { educators }\end{array}$ & $\begin{array}{c}\text { Lovin et al. } \\
\text { (2012) }\end{array}$ & USA \\
\hline $\begin{array}{l}\text { Learning of teaching in a collaborative } \\
\text { group: children's stories and } \\
\text { mathematics }\end{array}$ & $\begin{array}{c}\text { Souza \& } \\
\text { Oliveira } \\
(2013) \\
\end{array}$ & Brazil \\
\hline $\begin{array}{l}\text { Making Explicit the Commonalities of } \\
\text { MSP Projects: Learning from Doing }\end{array}$ & $\begin{array}{l}\text { Strutchens } \\
\text { \& Martin } \\
(2013)\end{array}$ & USA \\
\hline $\begin{array}{l}\text { Helping Pre-Service Mathematics } \\
\text { Teachers Connect Theory and } \\
\text { Practice: Using Reading, Writing, and } \\
\text { Observation Protocols to Structure } \\
\text { Field Experiences }\end{array}$ & $\begin{array}{l}\text { Cross \& } \\
\text { Bayazit } \\
(2014)\end{array}$ & USA \\
\hline $\begin{array}{l}\text { Changing perspectives on inclusive } \\
\text { mathematics education: Relationships } \\
\text { between research and teacher education }\end{array}$ & $\begin{array}{l}\text { Healy \& } \\
\text { Santos } \\
(2014) \\
\end{array}$ & Brazil \\
\hline $\begin{array}{l}\text { ICME international survey on } \\
\text { teachers working and learning through } \\
\text { collaboration }\end{array}$ & $\begin{array}{l}\text { Robutti et } \\
\text { al. (2016) }\end{array}$ & Italy \\
\hline $\begin{array}{l}\text { Reflections in a community of practice } \\
\text { on impossible triangles in mathematics } \\
\text { classes }\end{array}$ & \begin{tabular}{|c|} 
Solano, \\
Rico \& \\
Leal (2017) \\
\end{tabular} & Colombia \\
\hline
\end{tabular}

Source: Research data.
In another study, Boylan (2010) aimed to contribute to the discussion of the actor-network theory, indicating that the concepts addressed in this theory are useful to understand and direct changes in mathematics teacher practices. The article introduces the story of Clive, a mathematics teacher of elementary, middle, and high school students working in the United Kingdom for 35 years and taking part in a professional development program focused on collaborative work teaching geometry based on dynamic geometry softwares. Clive worked with a teacher called Anna in the planning and development of tasks, which addressed the circle theorems. Data were recorded in reports, individual interviews, and students' works. Clive acknowledged that the way he taught theorems was not significant to students and that a software helped them understand these theorems, enabling them to build knowledge by themselves. The positive results observed supported the adoption of changes in the practices used by Clive, which were thereafter based on the resources offered by softwares as well as the students' curiosity. This also improved the relationships between students and teachers in the classroom. Concerning the collaborative work between teachers, Clive declared that he did not feel embarrassed to try new strategies and that he was able to plan and evaluate his practices with other teachers.

Costa \& Lins (2010) presented a discussion about the importance of technologies in the education of mathematics teachers based on reflection and collective study. In this sense, the authors underscored aspects like (1) the resistance of teachers against the use of technology in classrooms; (2) the need to include technology in early education and the importance of class planning that considers how, where, and why to use technology; (3) the disposition of the teacher and the school management and staff to include technology in lessons despite the inherent difficulties; (4) the importance of collaborative environments between university and schools, when experiences are shared to overcome the fear to use new technologies.

In the study published by Cozza (2010), a collaborative environment between university and school was the main objective, which the author called Professional Development School (PDS). In this environment, in-service teachers, preservice teachers, and university professors develop a collaborative culture, in which all participants understand that they are learners. In order to understand how PDS transforms teaching culture in the classroom, the way it supports collaborative work, and whether it meets USA standards, 24 preservice teachers, three in-service teachers and one university professor took part in the project together with a group of fifth graders. The tasks developed addressed all mathematics topics The ethnographic method used included video and audio recordings, field notes, and conversations with groups held for 15 weeks. The author underscored the fact that, for PDS to evolve appropriately, all participants have to agree with the rules of group work, and the goals and strategies 
to assess these objectives have to be defined previously. The roles of each participant have to be characterized, and the ideas to improve knowledge have to be assessed. The results indicate that PDS was in accordance with USA standards, transforming classroom culture based on a learning context aimed at teaching practices and continuous interchange. It was possible to develop more efficacious to teach concepts using innovating ideas and trends in classrooms. In addition, all participants worked together in all stages, and underscored that the classroom is the environment where one learns by doing, teaching and collaborating. Nevertheless, the project suffered from a few problems, since the teachers' union complained that participant teachers were being given more attention and acknowledgement than the other teachers in the school district.

Slavit \& Nelson (2010) evaluated collaborative investigation activities in which learning theories were developed and mathematics tasks were carried out with a group of high school teachers in a school in the USA. In the article, two teachers called Camron and Bryce worked as moderators in the project groups, assigning tasks to colleagues and directing discussions. The data were obtained in weekly collaborative meetings that were recorded and transcribed, in addition to interviews with the two professors. In the data analysis, the ideas about teaching practices described in the participants' records were analyzed. The authors discovered that the investigation enabled the development of teaching theories, though it restricted the capacity of the group to use the student's thoughts in the process. For this reason, the moderators presented themselves as an element to support theories, promoting the participation of all members in the discussion of practices and collaborative development of these results. During meetings, the teachers improved a shared view of practices, which was possible due to collaborative research; yet, the participants expressed some degree of difficulty to critically discuss the students' thoughts. The authors concluded that, despite the issues concerning time and limited moderation, it was possible to develop teaching and learning theories collaboratively, mainly about how far a task is divided in stages or introduced as a general problem and how a content should be introduced before or during a task.

In the study published by Lovin et al. (2012), six NorthAmerican university mathematics professors developed a selfstudy with the aim of (1) understanding their own beliefs and how these influenced practices and (2) analyzing the influence of the self-study approach on their own teaching practices. The term self-study means the group analysis of practices with the help of third-party teachers in the effort to reformulate teaching practices in view of one professor's own beliefs and limitations (Lovin et al., 2012). Therefore, the research was carried out collaboratively between participants, who had finished their PhDs in the year 2000. The data were obtained from personal statements, a map of beliefs, e-mails and props used during teaching practices. The data were analyzed using interactions in the collaborative effort. After, the professors exchanged maps and statements in pairs, so as to allow one professor to understand the other's perspectives and to take notes that motivated a discussion. Four beliefs were shared by the participants, namely (1) mathematics is problematic and is generated based on construction of meaning, (2) learning in groups is more effective, (3) mathematics teachers have to be aware of the different contexts of students, (4) all levels of teaching are complex. Concerning the self-study results, the professors declared that collaborative reflections induced changes in their own practices, since ideas and practices of the other participants influenced their own work, improving it.

In order to shed light on how the development, analysis, and use of a children's storybook by collaborative work may become a source of knowledge to preservice teachers, Souza \& Oliveira (2013) invited five students of a course offered in a university who were working as mathematics teachers. Data were obtained from the daily notes taken during the development of the book, sketches, textbooks, class plans, class reports, and interviews and questionnaires prepared during the course using a collaborative approach. The books used covered various mathematical concepts, such as charts, sum, geometry, fractions, and others, and were prepared for early education groups. The authors discovered that the main contribution of the course was the preparation of didactic material that promoted both professional and personal learning, since teachers acknowledged their mistakes, learning to support one another, dialoguing with and listening to their peers. The teachers felt pleased with the fact that students learned and left behind the individualistic approach to the profession based on collaborative work. In addition, questions about teaching planning, mathematics content, teaching strategies, and problem solution could also be discussed and understood by the participating teachers, despite some difficulties. These issues included classroom management and the representation of mathematics contents. Therefore, collaborative work is important to the development of these teachers. These discussions promote dialogue, collaborative work, and mutual respect between professionals may be implemented during teacher preservice as well as in-service education, when everyone has the chance to learn.

The study published by Strutchens \& Martin (2013) presented the results obtained in seven projects implemented in schools in the USA in a partnership with North-American universities. The objective was to afford quality mathematics education to all elementary, middle, and high school students based on professional development built from collaborative work between universities and schools. This collaboration was mediated by Professional Learning Communities (PLC), whose premises include a mission, shared views and values, collective investigations and results that could be important to learning. Several PLCs were developed during this project conceived by mathematicians, mathematics educators, and mathematics teachers. The results also showed that all projects 
aimed at improvements in the mathematics knowledge or pedagogical competencies of teachers, which would lead to an improvement practices and, consequently, learning. Moreover, it was expected that students developed conceptual and procedural skills, helping teachers in the effort to teach classes having students as main subjects, questioning them and constructing their own discourse in the classroom. Some projects also addressed the importance of involving school managers in this collaborative processes. In order to observe the evolution of these projects, several instruments were developed by the groups themselves. Most used observation protocols in the classroom, or videos and transcriptions thereof. The authors concluded that in-house measures are less efficacious than projects involving third parties, since the group is able to identify problems and conceive solutions to these in addition to tools to assess the reach of the goals set qualitatively, since participants are thus able to acknowledge what happened and why.

Cross \& Bayazit (2014) investigated the impact of a collaborative project on the ability of preservice mathematics teachers to connect theory and practice. With that purpose, the project Theory-into-Practice (TIP) included 20 students of a North-American university who were required to research and develop individual and collective observation protocols prepared based on classroom observations accompanying a supervisor teacher. The authors analyzed and codified the data individually for subsequent comparison and final codification. Most teachers established connections between theory and the facts observed in the classroom during the development of protocols. Sometimes differences were observed between what supervising teachers taught in class and the students' opinions, who would try to talk about the materials read and formulate suggestions that, in many situations, were not accepted. The participants also reported their own experiences and possible actions to be taken in their future work. Yet, two of the 20 participants did not reach the conclusions expected by the researchers, since they seemed to be unmotivated and did not establish connections between theory and practice in an acceptable way, favoring experience. The collaborative approach between students and supervising teachers was not expected by the researchers, but it came to be a positive aspect of the project, since it afforded discussions that involved the teachers. As a rule, the authors believe that the TIP project had a positive impact on students, even though some measures had to be taken using a larger number of direct quotes from passages in the reports written, a wider sharing of readings with the supervising teachers, and more opportunities for participants to establish critical reflection.

Healy \& Santos (2014) discussed the participation in a collaborative project whose objective was to investigate several ways to approach and express mathematics. The authors analyzed the contribution of the project to develop didactic knowledge to teach mathematics inclusively. The research was carried out in an elementary school in São Paulo, Brazil and included eight seventh graders, of whom five were deaf. The concept investigated was geometric transformations based on reflection. Data were obtained from interviews with the participant teacher (one of the authors of the article) as a means to discover how motivated he was and define the concept to be addressed, since the proposal involved collaborative work. Videos recorded during planning and application of tasks in the school were also used. A pair work task was carried out by deaf students, hearing students, and mixed deaf and hearing student pairs using a software whose objective was to produce symmetric paths, exploring light reflection. All pairs concluded the task and identified the relationships. Hearing students found the task easier, because the software instructions were given as abbreviations and the terms symmetry and reflection were more common in Portuguese than in sign language. The deaf students used body movements in the discussions during the activity, prompting the teacher to ask all students to represent the activity as if they personified the software. This demonstrated an efficient way to afford communication between all students, which helped them all to express their ideas. The authors underscored the fact that collaboration helped overcome the divide between teaching and research, and that the two authors evolved both as researchers and teachers.

The literature review published by Robutti et al. (2016) reported the preliminary results of a research with teachers working collaboratively. Four research themes were conceived, namely (1) the nature of collaborative work and its relationship with culture and context, (2) the people taking part in this collaboration effort, (3) the theoretical perspectives and methodologies used, and (4) the learning obtained from collaborative work. The authors selected studies with mathematics teachers of all levels who collaborated with peers in research articles, conferences, books, manuals published between 2005 and 2015 in English, French, Italian, Japanese, Portuguese, and Spanish. In total, 316 publications were included and analyzed according to two approaches. The first was a systematic approach to specific information in each publication. The second was characterized as a synthesizing approach, which allowed identifying main topics in each publication that had any connection with the research questions. The results showed that collaborative work involves different groups of people, usually of researchers, who were the authors of the publications in most cases. Some studies did not discuss theory, but $80 \%$ of those that did alluded to some kind of "community". For the authors, it was not possible to clearly identify the ways learning was achieved and whether it resulted from collaboration or not. In addition, some publications did not discuss the importance of collaborative work between teachers. Time and other restrictions were the main obstacles to collaboration. The researchers listed the practices that remain useful after research, works that address 
learning using digital resources and collaborative effort, analyses covering mathematical learning of participating teachers, studies with teachers of elementary and middle school groups in a collaborative environment, and the ways to value teachers' opinions so that they become clear in research.

In the most recent study included in the present review, Solano, Rico, \& Leal (2017) described the meanings addressed in a community of practice formed by mathematics education undergraduates, post-graduates, mathematics professors, and elementary, middle, and high school teachers in Colombia who included digital technologies in classes. The participants had meetings every two weeks, when they planned classes and discussed their own practices based on the ReflectionAction theoretical model, from planning to post-lesson. In the article, the authors described a class given by one teacher only, called Mary, in which angles were described using the Logo tool in a group of eighth graders. The task suggested was the construction of a triangle whose angles were $70^{\circ}, 40^{\circ}$ and $70^{\circ}$ measuring 75,120 , and 120 units of length. But this triangle was impossible to build using the tool, so the students built one whose angles were $70^{\circ}, 37^{\circ}$, and $70^{\circ}$, presenting a mock geometrical shape that does not meet the alternate interior angle theorem. The teacher failed to clarify this issue in class, though she discussed it in subsequent meetings.
During the discussion with the community of practice, she acknowledged the importance of planning and reviewing all tasks before classes, mainly when technology is used. In addition, no participant had noticed these details during class planning, but the other teachers could understand these problems after collaborative consideration. Also, the tool used complemented the lesson, promoting learning, yet it did not solve all problems. It became clear that the technological resource had to be mastered side by side with pedagogical and mathematics contents.

\subsection{Horizontal analysis}

The vertical analysis of the articles included in this review enabled the identification of characteristics in common, which are presented below.

\subsubsection{Focus of the investigation}

Three categories of objectives or research questions were identified: (A) To include a group with potential collaborative characteristics and discuss its potentialities, (B) to analyze the tasks that were developed and implemented collaboratively, and (C) to approach collaborative work as a means to test theories and use methodologies and tools (Table 2).

Table 2 - Categories of objectives or research questions

\begin{tabular}{|c|c|c|c|c|c|c|c|c|c|c|c|c|}
\hline & $\begin{array}{l}\text { Silverman } \\
\text { \& Clay } \\
(2009)\end{array}$ & $\begin{array}{c}\text { Boylan } \\
(2010)\end{array}$ & $\begin{array}{l}\text { Costa } \\
\text { \& Lins } \\
(2010)\end{array}$ & $\begin{array}{l}\text { Cozza } \\
(2010)\end{array}$ & $\begin{array}{c}\text { Slavit \& } \\
\text { Nelson } \\
(2010)\end{array}$ & $\begin{array}{l}\text { Lovin } \\
\text { et al. } \\
(2012)\end{array}$ & $\begin{array}{c}\text { Souza \& } \\
\text { Oliveira } \\
(2013)\end{array}$ & $\begin{array}{c}\text { Strutchens } \\
\text { \& Martin } \\
\text { (2013) }\end{array}$ & $\begin{array}{c}\text { Cross \& } \\
\text { Bavazit } \\
(2014)\end{array}$ & $\begin{array}{c}\text { Healy \& } \\
\text { Santos } \\
(2014)\end{array}$ & $\begin{array}{c}\text { Robutti } \\
\text { et al. } \\
(2016)\end{array}$ & $\begin{array}{c}\text { Solano, } \\
\text { Rico } \\
\& \text { Leal } \\
(2017)\end{array}$ \\
\hline A & & & & $X$ & & & & $\mathrm{X}$ & $X$ & $X$ & $X$ & \\
\hline $\mathrm{B}$ & $X$ & & & & $X$ & & $X$ & & & & & $X$ \\
\hline $\mathrm{C}$ & & $X$ & $\mathrm{X}$ & & & $X$ & & & & & & \\
\hline
\end{tabular}

Source: Research data.

\subsubsection{Methodology and character of the studies}

The vertical analyses of the articles showed that only two studies were theoretical in character (Costa \& Lins, 2010; Robutti et al., 2016). All studies included followed a qualitative approach, which concedes that knowledge considered true is dynamic at a given point in time, and may change. In addition, a qualitative research is based on qualitative procedures that are based on the premise that knowledge is not neutral, being affected by values, intentions, background of the researcher, and social and political scenario (Johnson \& Christensen, 2004). This is shown in Table 3, which illustrates the data collection systems used in the studies.

Table 3 - Data collection instruments

\begin{tabular}{|c|c|c|c|c|c|c|c|c|c|c|}
\hline & $\begin{array}{l}\text { Silverman } \\
\text { \& Clay } \\
\text { (2009) }\end{array}$ & $\begin{array}{l}\text { Boylan } \\
(2010)\end{array}$ & $\begin{array}{l}\text { Cozza } \\
(2010)\end{array}$ & $\begin{array}{l}\text { Slavit \& } \\
\text { Nelson } \\
\text { (2010) }\end{array}$ & $\begin{array}{l}\text { Lovin et } \\
\text { al. (2012) }\end{array}$ & $\begin{array}{c}\text { Souza \& } \\
\text { Oliveira } \\
(2013)\end{array}$ & $\begin{array}{l}\text { Strutchens \& } \\
\text { Martin (2013) }\end{array}$ & $\begin{array}{c}\text { Cross \& } \\
\text { Bavazit } \\
(2014)\end{array}$ & $\begin{array}{c}\text { Healy \& } \\
\text { Santos } \\
(2014)\end{array}$ & $\begin{array}{c}\text { Solano, } \\
\text { Rico \& Leal } \\
(2017)\end{array}$ \\
\hline Class planning & & & $\mathrm{X}$ & & & $\mathrm{X}$ & & & $\mathrm{X}$ & $\mathrm{X}$ \\
\hline Videos & & & $\mathrm{X}$ & & & & $\mathrm{X}$ & & $X$ & \\
\hline Interviews & & $X$ & & $\mathrm{X}$ & & $\mathrm{X}$ & & & $\mathrm{X}$ & \\
\hline Questionnaires & & & & & & $X$ & & & & \\
\hline Narratives & & & & & $\mathrm{X}$ & & & & & \\
\hline Reports & & $X$ & & & & $X$ & & $\mathrm{X}$ & & \\
\hline Tasks & $\mathrm{X}$ & & & & $\mathrm{X}$ & & & $\mathrm{X}$ & & \\
\hline $\begin{array}{l}\text { Group } \\
\text { Discussions }\end{array}$ & $\mathrm{X}$ & & $X$ & $\mathrm{X}$ & $\mathrm{X}$ & & & & & $X$ \\
\hline
\end{tabular}




\subsubsection{Mathematics domain}

Six studies explained the mathematics domain addressed. Table 4 shows that most papers covered the teaching of geometry. It is interesting to underline that some studied addressed more than one mathematics domain.

Table 4 - Mathematics domain

\begin{tabular}{|l|c|c|c|c|c|c|}
\hline & $\begin{array}{c}\text { Silverman } \\
\text { \& Clay } \\
(2009)\end{array}$ & $\begin{array}{c}\text { Boylan } \\
(2010)\end{array}$ & $\begin{array}{c}\text { Cozza } \\
(2010)\end{array}$ & $\begin{array}{c}\text { Souza } \\
\text { Oliveira } \\
(2013)\end{array}$ & $\begin{array}{c}\text { Healy } \\
\text { \& } \\
\text { Santos } \\
(2014)\end{array}$ & $\begin{array}{c}\text { Solano, } \\
\text { Rico } \\
\text { \& Leal } \\
(2017)\end{array}$ \\
\hline Algebra & & & $\mathrm{X}$ & & & \\
\hline Geometry & & $\mathrm{X}$ & $\mathrm{X}$ & $\mathrm{X}$ & $\mathrm{X}$ & $\mathrm{X}$ \\
\hline Arithmetic & $\mathrm{X}$ & & $\mathrm{X}$ & $\mathrm{X}$ & & \\
\hline
\end{tabular}

Source: Research data.

\subsubsection{Country of origin}

Half the number of studies included were carried out in the USA. Also, 25\% of the studies were published by Brazilian authors. Considering that one study was published in Colombia, in total $83 \%$ of the articles included were conducted in the Americas. Despite the fact that we used five databases, it was not possible to include papers published in all continents. We underscore the inclusion of a small number of collaborative efforts carried out in Europe and the lack of any such study published in Asia, Africa, and Oceania.

\subsubsection{Teacher education}

Based on the focus on collaborative work between teachers during teacher education, we could observe two periods, preservice education and in-service education.

Table 5 - Teacher education

\begin{tabular}{|c|c|c|c|c|c|c|c|c|c|c|c|}
\hline & $\begin{array}{c}\text { Silverman } \\
\text { \& Clay } \\
(2009)\end{array}$ & $\begin{array}{c}\text { Boylan } \\
(2010)\end{array}$ & $\begin{array}{c}\text { Cozza } \\
(2010)\end{array}$ & $\begin{array}{c}\text { Slavit \& } \\
\text { Nelson } \\
(2010)\end{array}$ & $\begin{array}{c}\text { Lovin et } \\
\text { al. (2012) }\end{array}$ & $\begin{array}{c}\text { Souza \& } \\
\text { Oliveira } \\
(2013)\end{array}$ & $\begin{array}{c}\text { Strutchens } \\
\text { \& Martin } \\
(2013)\end{array}$ & $\begin{array}{c}\text { Cross \& } \\
\text { Bavazit } \\
(2014)\end{array}$ & $\begin{array}{c}\text { Healy \& } \\
\text { Santos } \\
(2014)\end{array}$ & $\begin{array}{c}\text { Robutti } \\
\text { et al. } \\
(2016)\end{array}$ & $\begin{array}{c}\text { Solano, } \\
\text { Rico \& } \\
\text { Leal (2017) }\end{array}$ \\
\hline $\begin{array}{c}\text { Preservice } \\
\text { education }\end{array}$ & & & $\mathrm{X}$ & & & $\mathrm{X}$ & & $\mathrm{X}$ & & \\
\hline $\begin{array}{c}\text { In-service } \\
\text { education }\end{array}$ & $\mathrm{X}$ & $\mathrm{X}$ & $\mathrm{X}$ & $\mathrm{X}$ & $\mathrm{X}$ & & $\mathrm{X}$ & & $\mathrm{X}$ & $\mathrm{X}$ & $\mathrm{X}$ \\
\hline
\end{tabular}

Source: Research data.

Table 5 shows that studies covering in-service teacher education were more prevalent in the studies selected. However, in order to facilitate the collaborative environment, we highlight the studies published by Cozza (2010) and Solano, Rico, and Leal (2017), since they included preservice and in-service teachers. The work published by Robutti et al. (2016), despite being a literature review, included only research on continuous education.

\subsubsection{Teaching level}

During the selection of studies for this systematic literature review, we noticed that all teaching levels were included in at least one study. Also, $25 \%$ of the publications included covered one or more levels (Table 6), which underscores the collaborative nature of these studies, not restricting the approach to a given audience.

Table 6 - Teaching levels covered in the studies

\begin{tabular}{|c|c|c|c|c|c|c|c|c|c|c|c|c|}
\hline & $\begin{array}{c}\text { Silverman } \\
\text { \& Clay } \\
(2009)\end{array}$ & $\begin{array}{c}\text { Boylan } \\
(2010)\end{array}$ & $\begin{array}{c}\text { Costa } \\
\text { \& Lins } \\
(2010)\end{array}$ & $\begin{array}{c}\text { Cozza } \\
(2010)\end{array}$ & $\begin{array}{c}\text { Slavit \& } \\
\text { Nelson } \\
(2010)\end{array}$ & $\begin{array}{c}\text { Lovin } \\
\text { et al. } \\
(2012)\end{array}$ & $\begin{array}{c}\text { Souza \& } \\
\text { Oliveira } \\
(2013)\end{array}$ & $\begin{array}{c}\text { Strutchens } \\
\text { \& Martin } \\
(2013)\end{array}$ & $\begin{array}{c}\text { Cross \& } \\
\text { Bavazit } \\
(2014)\end{array}$ & $\begin{array}{c}\text { Healy \& } \\
\text { Santos } \\
(2014)\end{array}$ & $\begin{array}{c}\text { Robutti } \\
\text { et al. } \\
(2016)\end{array}$ & $\begin{array}{c}\text { Solano, } \\
\text { Rico \& } \\
\text { Leal (2017) }\end{array}$ \\
\hline $\begin{array}{c}\text { Elementary } \\
\text { school }\end{array}$ & $\mathrm{X}$ & & & $\mathrm{X}$ & & & $\mathrm{X}$ & $\mathrm{X}$ & & & $\mathrm{X}$ & \\
\hline $\begin{array}{c}\text { Middle } \\
\text { school }\end{array}$ & $\mathrm{X}$ & $\mathrm{X}$ & & & & & & $\mathrm{X}$ & $\mathrm{X}$ & $\mathrm{X}$ & $\mathrm{X}$ & $\mathrm{X}$ \\
\hline $\begin{array}{c}\text { High } \\
\text { school }\end{array}$ & $\mathrm{X}$ & $\mathrm{X}$ & & & $\mathrm{X}$ & & & $\mathrm{X}$ & & & $\mathrm{X}$ & \\
\hline University & & & & & & $\mathrm{X}$ & & & & & $\mathrm{X}$ & \\
\hline
\end{tabular}

Source: Research data.

\subsubsection{Discussions}

The analysis of the results and conclusions published by the articles included in this review highlights the characteristics observed in collaboration environments, such as partnership between participants, defined roles of each teacher, and mutual support and respect, for example. We noted the significant number of studies covering collaborative context with technologies, despite the limitations observed in this aspect, such as lack of motivation or poor participation. By working collaboratively, teachers acknowledge their own difficulties and limitations, searching for new approaches for their lessons, feeling more confident to "run risks" and more inclined to accept the practices of a coworker. Therefore, the studies included motivated the development of collaborative environments that involve university and school as well as preservice and in-service education, since everybody learns, whether they are students, teachers, or researchers. 


\section{Conclusion}

The vertical and horizontal analyses of the studies included in this systematic review revealed that these publications shared characteristics in common, like the qualitative approach, the empirical nature of research, continuous teacher education, and the use of data collection tools like group discussions and class planning. The categories of objectives or research questions were (1) to include a group with potential collaborative characteristics and discuss its potentialities, (2) to analyze the tasks that were developed and implemented collaboratively, and (3) to approach collaborative work as a means to test theories and use methodologies and tools.

Based on this, we underscored three factors observed in collaborative environments that promote teaching processes in mathematics education, namely (1) class planning, (2) teaching practice, and (3) knowledge production. The importance of class planning is evident, and was investigated in the studies included in this review (Boylan, 2010; Costa \& Lins, 2010; Healy \& Santos, 2014; Solano, Rico \& Leal, 2017; Souza \& Oliveira, 2013). When planning classes in a collaborative environment, teachers may feel more confident to develop tasks, since they are involved in group discussions. The other participants may help identify any gaps or difficulties, suggesting ideas and sharing experiences, which in turn is associated with the second factor, teaching practice.

Teaching practice includes the valuing of teaching experience, the analysis of what happens in a classroom, and the solution to questions proposed by students. Collaboration enables teachers, mainly those taking continuous education, to feel part of the education process. Education projects to or about teachers are not enough; it is necessary to develop education processes with teachers, meeting their expectations and acknowledging their experiences, their knowledge of practices, and what takes place in a classroom, as observed in the study published by Rowland, Huckstep and Thwaites (2005). Collaborative work stands as a means to this end, narrowing the distance between university and school, between researchers and students of in-service teachers besides enabling all parties involved in this process to learn and teach (Healy \& Santos, 2014; Lovin et al., 2012).

We understand that collaborative work improves knowledge production during teacher education, whether this knowledge is mathematical, didactic, school, and social, for instance, since, as observed in the categories of objectives of the horizontal analysis we conducted, theories, methodologies, and tools are used based on collaboration. Therefore, when the teacher education process considers teaching practice and the knowledge acquired by each participant, everyone may contribute to the production of new knowledge, whether through group discussions, class planning, or analysis of events, always respecting personal experiences and keeping in mind that collaborative work allows mutual learning (Souza \& Oliveira, 2013).
Therefore, based on the studies included in this review, we understand that collaborative work may promote mathematics teacher education through class planning, teaching practice, and knowledge production. Nevertheless, establishing collaborative work may not be a simple task. Difficulties associated with time, unmotivated or excessively shy participants, and lack of support from the education organization were mentioned in the studies included (Cozza, 2010; Cross \& Bayazit, 2014; Silverman \& Clay, 2009; Slavit $\&$ Nelson, 2010). Some of these problems were addressed by Robutti et al. (2016).

Since we restricted this review to articles, we may have left out important information present in books and conference proceedings. On the other hand, we included papers published in four databases in the effort to enlarge the scope of publications as a means to broaden the horizon of research published in Portuguese, English, and Spanish. We expected to find studies published across the world, which unfortunately did not happen. The language barrier may have been on obstacle in this effort. Also, our query terms and selection criteria, despite encompassing, may have left out relevant publications that used terms different from collaboration, instead of collaborative.

All in all, in view of the difficulties found in working collaboratively, it is necessary to acknowledge the possibilities open by collaborative effort and its advantages in mathematics teacher education, as observed both in the horizontal and vertical analyses carried out and in the conclusion of this review. Our study shows how collaborative work may be useful in teaching processes as well as in the production and evaluation of knowledge of teachers.

\section{Acknowledgement}

This study was financed in part by the Coordenação de Aperfeiçoamento de Pessoal de Nível Superior - Brasil (CAPES) - Finance Code 001.

\section{References}

Bednarz, N., Fiorentini, D., \& Huang, R. (2011). International Approaches to Professional Development for Mathematics Teachers. Ottawa: University of Ottawa Press.

Boylan, M. (2010). 'It's getting me thinking and I'm an old cynic': exploring the relational dynamics of mathematics teacher change. J. Mathem. Teacher Educ., 13 (5), 383-395.

Costa, M. L. C., \& Lins, A. F. (2010). Trabalho colaborativo e utilização das tecnologias da informação e comunicação na formação do professor de Matemática. Educação Matemática Pesquisa, 12 (3), 452-470.

Cozza, B. (2010). Transforming Teaching Into A Collaborative Culture: An attempt to create a professional development school-university partnership. The Educational Forum, 74 (3), 227-241

Crecci, V. M., \& Fiorentini, D. (2011). Teacher professionality and professional development in communities of practice: The case of Collaborative Groups. Proceedings of the International Study Association on Teachers and Teaching 
(ISATT), Braga, Portugal, 15.

Cross, S. B., \& Bayazit, N. T. (2014). Helping pre-service mathematics teachers connect theory and practice: Using reading, writing, and observation protocols to structure field experiences. Teacher Education Quarterly, 41 (2), 51-71.

Depaepe, F., Verschaffel, L., \& Kelchtermans, G. (2013). Pedagogical content knowledge: a systematic review of the way in which the concept has pervaded mathematics educational research. Teaching and Teacher Education, 34 (1), 12-25.

Hadar, L., \& Brody, D. (2010). From isolation to symphonic harmony: Building a professional development community among teacher educators. Teaching and Teacher Education, $26,1641-1651$

Healy, L., \& Santos, H. F. (2014). Changing perspectives on inclusive mathematics education: Relationships between research and teacher education. Education as Change, 18 (1), 121-136.

Johnson, R. B., \& Christensen, L. B. (2004). Educational research: Quantitative, qualitative, and mixed approaches. Boston: Allyn and Bacon.

Lovin, L. H., Sachez, W. B., Leatham, K. R, Chauvot, J. B., Kastberg, S. E., \& Norton, A. H. (2012). Examining Beliefs and Practices of Self and Others: Pivotal points for change and growth for mathematics teacher educators. Studying Teacher Education, 8 (1), 51-68.

Nacarato, A. M., \& Grando, R. C. (2008). Formative process: sharing learning experiences in Geometry. Proceedings of the International Congress on Mathematical Education (ICME), Monterrey, Mexico, 11.
Robutti, O., Cusi, A., Clark-Wilson, A., Jaworski, B., Chapman, O., Esteley, C., Goos, M., Isoda, M., \& Joubert, M. (2016). ICME international survey on teachers working and learning through collaboration: June 2016. ZDM Mathematics Education, 48 (5), 651-690.

Rowland, T., Huckstep, P., \& Thwaites, A. (2005). Elementary Teachers' Mathematics Subject Knowledge: the Knowledge Quartet and the Case of Naomi. Journal of Mathematics Teacher Education, 8 (3), 255-281.

Silverman, J., \& Clay, E. L. (2009). Online Asynchronous Collaboration in Mathematics Teacher Education and the Development of Mathematical Knowledge for Teaching. The Teacher Educator, 45 (1), 54-73.

Slavit, D., \& Nelson, T. H. (2010). Collaborative teacher inquiry as a tool for building theory on the development and use of rich mathematical tasks. Journal of Mathematics Teacher Education, 13 (3), 201-221.

Solano, L. A. C., Rico, S. E. P., \& Leal, J. E. F. (2017). Reflexiones en comunidad de práctica sobre Triángulos Imposibles en clase de matemáticas. Educação e Pesquisa, 43 (2), 453-466.

Souza, A. P. G., \& Oliveira, R. M. M. A. (2013). Aprendizagem da docência em grupo colaborativo: histórias infantis e matemática. Educação e Pesquisa, 39 (4), 859-874.

Stahnke, R., Schueler, S., \& Roesken-Winter, B. (2016). Teachers' perception, interpretation, and decision-making: a systematic review of empirical mathematics education research. ZDM Mathematics Education, 48, 1-27.

Strutchens, M., \& Martin, W. G. (2013). Making Explicit the Commonalities of MSP Projects: Learning from Doing. The Mathematics Enthusiast, 10 (3), 777-791. 